\title{
Leucism in the three-striped palm squirrel (Funambulus palmarum) at Gudalur Forest Division, Tamil Nadu, Southern India
}

\author{
Arockianathan Samson ${ }^{* 1}$, Balasundaram Ramakrishnan ${ }^{1}$ and Subbaiah Bargavi²
}

\footnotetext{
${ }^{1}$ Mammalogy and Forest Ecology Lab, Department of Zoology and Wildlife Biology, Government Arts College, Udhagamandalam 643 002, The Nilgiris, Tamil Nadu, Southern India. Email: kingvulture1786@gmail.com (AS), bio.bramki@gmail.com (BR).

${ }^{2}$ Forest College and Research Institute, Mettupalayam - 641301. Southern India. Email: bargavi.ti@gmail.com (SB).

*Corresponding authors:
}

Leucism is a condition characterized by the reduction of all skin pigmentation, generally observed in animals. In this note we describe the first known cases of the leucism in the three-striped palm squirrel in the fragmented forest habitat of Gudalur forest division, Tamil Nadu, Southern India.

El leucismo es una afección caracterizada por la reducción de toda la pigmentación de la piel, generalmente observada en animales. En esta nota describimos los primeros casos conocidos de leucismo en la ardilla de palmera de tres rayas en el hábitat forestal fragmentado de la división de bosques de Gudalur, Tamil Nadu, sur de la India.

Key Words: Gudalur; Leucism; Southern India; Tamil Nadu; Three-striped palm squirrel.

๑ 2017 Asociación Mexicana de Mastozoología, www.mastozoologiamexicana.org

The observation of color abnormalities in wild mammals is an isolated event because these abnormalities are rare (Robinson 1973; Caro 2005). Inherited color defects, such as albinism and leucism, are well known in several animal species. Leucism is a condition in which there is partial loss of pigmentation in an animal resulting in white, pale, or patchy coloration of the skin, hair, feathers, scales or cuticle, but not the eyes. Unlike albinism, it is caused by a reduction in multiple types of pigments, not just melanin (Rook et al. 1998). Leucisitic animals appear white in colour; this condition is controlled by a single recessive allele (Owen and Shimmings 1992). In this note we describe the first known cases of leucism in the threestriped palm squirrel inhabiting the fragmented forest habitat of Gudalur forest division, Tamil Nadu, Southern India.

The three-striped palm squirrel (Funambulus palmarum) is a small rodent species that belongs to the family Sciuridae. There are four subspecies of Indian palm squirrels that are native to India and Sri Lanka; the species studied is endemic to southern India and Sri Lanka (Nameer and Molur 2008; Thorington and Hoffmann 2005). It is widely distributed, from sea level up to $2,000 \mathrm{~m}$ asl (Nameer and Molur 2008). The three-striped palm squirrel can reach 6 to 7.8 inches in total length and weigh 100 to $120 \mathrm{~g} \mathrm{(3.5}$ to 4.2 ounces) (Menon 2003). It is covered with short fur that is yellowish brown or brown colored on the back and creamy white on the belly (Menon 2003). It has three white stripes on the back that stretch from head to tail. It has dark rounded eyes, small triangular ears, long front teeth and bushy tail (Figure-1a; Prater1971 \& 1980; Menon 2003; Pradhan and Talmale 2012). It is an omnivore and its diet is mostly based on fruits and nuts, but it also consumes eggs, small birds, larvae and insects (Prasad et al. 1966; Malhi and Kaur 1994; Malhi and Khushrupinder 1995).

On 22 September 2016, at 13:39 hours we observed one leucistic F. palmarum specimen in the fragmented forest habitat of Gudalur forest division, Tamil Nadu, Southern India ( $\left.\mathrm{N} 11.493667^{\circ}, \mathrm{E} 76.336977^{\circ}\right)$; it was totally white, with pinkish snout, ears and limbs, but its eyes were normal colored (Figure-1b); it appears to be a case of leucism and not albinism, where the whole body is totally white with reddish eyes (Smielowski 1987). Sayyed et al. (2015) reported albinism in jungle palm squirrels (Funambulus tristriatus) from Goa, India; in addition, Sayyed and Mahabal (2016) recorded the first known record of leucism in another species of the same genus, the five-striped palm squirrel (Funambulus pennantii) from Maharashtra, India. A total of three squirrel species are found in India, namely three-striped palm squirrel, five-striped palm squirrel and jungle palm squirrel; the five-striped palm squirrel is found in northern India, while the jungle and the three-striped palm squirrels are located in southern India, especially in the Western Ghats mountain region (Prater 2005; Menon 2003). The occurrence of leucism is associated with many factors such as pollution, environmental alterations (Moller and Mousseau 2001), low-quality diet (Owen and Shimmings 1992; Peles et al. 1995), or follicular damage (Phillips 1954; Hafner and Hafner 1987). Leucism is more frequent in small and isolated populations due to inbreeding, which causes recessive alleles to be expressed (Holyoak 1978; Bensch et al. 2000). Leucism reports are relatively rare in small mammals (Robinson 1973; Caro 2005; Steen and Sonerud 2012). Leucistic individuals have lower survival rates than normally colored individuals, because they are more 


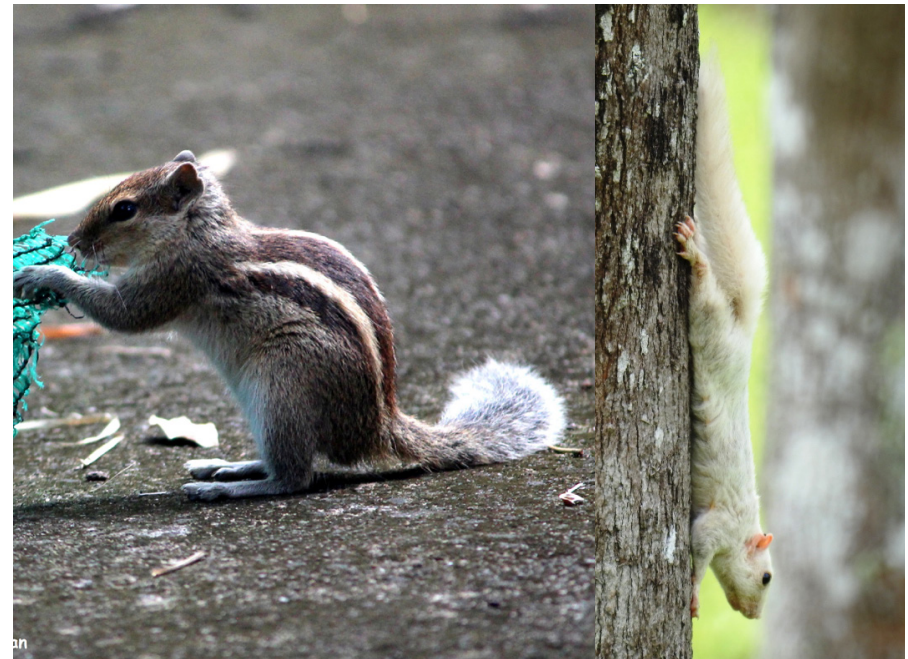

Figure 1. a) Normal Three striped Palm Squirrel. b) Leucism affected Three Striped Palm Squirrel.

easily detected by predators (Owen and Shimmings 1992). It is worth mentioning that there are probably many animal species from different orders with anomalous coloration; unfortunately, many of these records have not been officially reported, probably due to lack of knowledge. Therefore, we highlight the relevance of photographs as valuable tools for the documentation of natural history as a whole. In conclusion, researchers should be encouraged to report records of leucism in wildlife in order to better understand this phenomenon and the insights into the ecological and physiological implications of this condition, which has a significant effect on animal survival (Fertl et al. 2004).

\section{Literature Cited}

Bensch, S., B. Hansson, D. Hasselouist, and B. Nielsen. 2000. Partial albinism in a semi-isolated population of great reed warblers. Hereditas 133:167-170.

CARO, T. I. M. 2005. The Adaptive significance of coloration in Mammals. BioScience 55: 125-136

Fertl, D., N. B. Barros, R. A. Rowlett, S. Estes, and M. Richlen. 2004. An update on anomalously white cetaceans, including the first account for the pantropocal spotted dolphin (Stenella attenuata graffmani). Latin American Journal of Aquatic Mammals $3: 163-166$.

Hafner, M., and D. Hafner. 1987. Geographic distribution of two Costa Rican species of Orthogeomys, with comments on dorsal pelage marking in the Geomyidae. Southwestern Naturalist 32:5-11.

Holyoak, D. T. 1978. Variable albinism of the flight feathers as an adaptation of recognition of individual birds in some Polynesian populations of Acrocephalus warblers. Ardea 66:112-117.

MaLHI, C. S., AND K. KaUR. 1994. Responses of Funambulus pennantii Wroughton (Rodentia, Sciuridae) towards different food additives. Mammalia 59:373-384.

MALHI, C. S., AND K. KHUSHRUPINDER. 1995. Food preference behavior of the five striped squirrel, Funambulus pennanti Wroughton. Behavioural Processes 34:55-65.
Menon, V. 2003. A field guide to Indian mammals. Dorling kindersley (India) Pvt. Ltd. and Penguin Book India (P.) Ltd. Delhi, India.

Moller, A. P., AND T. A. Mousseau. 2001. Albinism and phenotype of barn swallows (Hirundo rustica) from Chernobyl. Evolution 55:2097-2104.

Nameer, P. O., AND S. Molur. 2008. Funambullus palmarum In: IUCN 2017-1. IUCN Red List of Threatened Species. Retrieved 21 January 2017.

Owen, M., And P. Shimmings. 1992. The occurrence and performance of leucistic Barnacle Geese, Branta leucopsis. Ibis 134:22-26.

Peles, J. D., M. F. Lucas, and G. W. Barkett. 1995. Population dynamics of agouti and albino meadow voles in high-quality, grassland habitats. Journal of Mammalogy 76:1013-1019.

PHILLIPS, A. R. 1954. The cause of partial albinism in a greattailed grackle. Wilson Bulletin 66:66.

Pradhan, M. S., AND S. S. Talmale. 2012. Indian Mammals: Checklist with comments on type locality, distribution, conservation, status and taxonomy. Nature Books India, Kolkata, India.

Prasad, M. R. N., G. K. Dhaliwal, P. Seth, A. H.redDi, A. K. Sivashankar, AND N. K. UBERO .1966. Biology of reproduction in the Indian palm squirrel, Funambulus pennanti (Wroughton). Symposia of the Zoological Society of London 15:353-364.

PrateR, S. H. 1971. The book of Indian animals. Bombay Natural History Society. Parshad, V.C. 1999. Rodent Control in India. Integrated Pest Management Reviews 4:97-126.

Prater, S. H. 1980. The Book of Indian Animals. Bombay Natural History Society and Oxford University Press, India.

Prater, S.H. 2005. The Book of Indian Animals. Bombay Natural History Socity, Oxford University Press, India

Robinson, R. 1973. Acromelanic albinism in mammals. Genetica 44:454-458.

Rook, A., D. S. Wilkinson, F. J. B. Ebling, R. H. Champion and J. L. Burton (eds.). 1998. Textbook of dermatology. 4th edn. Blackwell Scientific Publications. Oxford, England.

Sayyed, A., A. Mahabal and A. Nale. 2015. A first record of albinism in Jungle Palm Squirrels Funambulus tristriatus (Rodentia: Sciuridea) from India. Zoo's Print 30:18-19.

Sayyed, A., and A. Mahabal. 2016. First Record of Leucism in Five-striped Palm Squirrel Funambuluspennantii (Rodentia: Sciuridae) from India. Small Mammal Mail - Bi-Annual Newsletter of Chiroptera, Rodentia, Insectivora, \& Scandentia Conservation and Information Networks of South Asia 8:8 SMIELOWSKI, J. 1987. Albinism in the blue bull or nilgai, Boselaphus tragocamelus (Pallas, 1766). Journal of the Bombay Natural History Society 84:427-429.

Steen, R., AND G. A. Sonerud. 2012. A bank vole (Myodes glareolus) with complete leucismo captured by a Eurasian kestrel (Falco tinnunculus) in Norway. Annales Zoologici Fennici 49:306-308. Thorington, R. W., AND R. S. Hoffmann. 2005. Family Sciuridae In Mammal Species of the World: a taxonomic and geographic reference (Wilson, D. E., and D. M. Reeder, ed). The Johns Hopkins University Press. Baltimor, U. S. A.

\section{Associated editor: Lia Méndez}

Submitted: May 2, 2017; Reviewed: June 14, 2017;

Accepted: June 22, 2017; Published on line: July 6, 2017. 